\title{
The Dilemma of Civil Society in Cameroon Since 1990: Which Way Forward?
}

Walter Gam Nkwi*

\begin{abstract}
The role of civil society in societal transformation and nation building in Cameroon has been compromised by political and social structures created during three decades of autocratic rule that still underline the practical and moral workings of the state today. Civil society remains mired in societal cleavages that find expression in parochial tendencies ranging from ethnicism to regionalism. As a result civil society's ability to mobilise all and sundry towards a meaningful democratic culture is limited. In this context the quest for good governance has remained, for the vast majority of Cameroonians, a platitudinous utopia. This paper argues that only a civil society that transcends narrow social and political boundaries and identifies with the daily and legitimate struggles of ordinary citizens can serve as a signpost pointing towards meaningful quantitative and qualitative development in Cameroon.
\end{abstract}

\section{Résumé}

Le rôle de la société civile dans la transformation de la société et dans la construction nationale au Cameroun a été compromis par les structures politiques et sociales créées au cours de trois décennies de pouvoir autocratique qui marquent encore les mécanismes pratique et moral de l'état aujourd'hui. La société civile reste plongée dans les clivages sociaux qui trouvent leur expression dans des tendances d'esprit de clocher allant de l'ethnisme au régionalisme. En conséquence, la capacité de la société civile à mobiliser tout le monde en

\footnotetext{
* Department of History, University of Buea, PO Box 63 Buea, Cameroon.

E-mail: nkwiwally@yahoo.com
} 
faveur d'une culture démocratique significative est limitée. Dans ce contexte, la quête de bonne gouvernance demeure, pour une vaste majorité des Camerounais, une banale utopie. Il est démontré ici que seule une société civile ayant transcendé les étroites frontières sociales et politiques et s'identifiant aux luttes quotidiennes et légitimes des simples citoyens peut servir de poteau indicateur signalant la direction à suivre pour un développement significatif tant quantitatif que qualitatif au Cameroun.

\section{Introduction}

Like most countries in Africa, Cameroon is a colonial construct. It has its specificities and paradoxes, which can be quite mesmerising. Cameroon is one place where logic does not always have its way, where outcomes are never predictable. For example, in one country where the price of bread is raised by 33 cents, the whole country is expected to go up in flames. But in Cameroon, the currency is devalued by 100 percent, followed immediately by a 70 percent slash in civil service salaries, and not a finger is raised. Cameroon tops the Transparency International world corruption index one year (1998) and is sufficiently comfortable with that performance to repeat the feat the next year. To the best of this writer's knowledge Cameroon is also the only country in the world with two constitutions, each operating according to the whims and caprices of the ruling government. The country is a vastly wealthy triangle, yet its entry into the Heavily Indebted Poor Countries Initiative (HIPC) is celebrated as a national achievement. Cameroon is one of only a few countries in Africa to have had three colonial masters, Germany, France and Britain, and has serpentined through AngloFrench trusteeship, federalism and the unitary state, to what is today just the state.

Even natural cataclysms respect the strange ways of this country. Mount Cameroon, West Africa's highest peak, erupted in 1999, but the lava flew down the slopes away from human settlements. The onekilometre-wide blazing liquid flew downhill for close to fifteen kilometres, destroying all the vegetation, but stopped a few metres from a hotel complex and within sight of the country's only oil refinery. At the end, not a single person died. Cameroon has the poorest football pitches anywhere in Africa but the richest football fame in Africa, having won the African Cup of Nations in 1984, 1988, 2000 and 2002. It has participated in the World Cup finals five times and is the first African country to reach the quarterfinals of the World Cup. Geographically, 
even Cameroon's location is ambiguous, with an English-speaking sector located in West Africa and a French-speaking sector in Central Africa

Since 1961 Cameroon has been ruled by two presidents who combined the tactics of divide and rule, Machiavellianism and outright totalitarianism, except for the brief period of 1982 to 1984 when Paul Biya, the second president, introduced a dicey policy of liberalism, but when a coup d'état threatened to eliminate him he became a dictator, and any signs of opposition were driven underground.

However dictatorial rule did not go on forever. The last decade of the twentieth century witnessed debates over the role of citizens in societal transformation in Cameroon in particular and Africa in general after the end of the Cold War, the reunification of Germany and the failure of African totalitarian states to provide minimum social, economic and political resources to their citizens. More especially, the question was pivoted around what strategies, options and forces could be amalgamated to promote democratic transition within internationally recognised norms while taking into consideration the local history and the political and economic peculiarities of the state (Mbuagbo and Fru 2003).

In Cameroon the challenge of civil society has been to create awareness in citizens that will encourage them to take responsibility for their individual and collective destinies (Mbuagbo and Robert 2004). Unfortunately the liberties of citizens as found in the constitution have remained so far a dead letter. Civil society is fractured, and the flavour of its vibrancy has gone sour. In any ordinary sense civil society deals with day-to-day operations of livelihood and one should be able to talk of civil society when it has an impact on the society; if not it should be left out. However civil society has occasioned endless disputes over definitions, and its study in Africa has made great strides (Comaroff and Comaroff 1999; Kasfir 1998; Sitoe 1998; Osaghae 1994). Some scholars have seen civil society in terms of advancing democracy and disciplining the state to ensure that citizen interest are taken seriously and greater civil and political participation is fostered (Carothers 2000). Others have conceived of civil society as a critical element of democratisation, arguing that the current failure of the process of democratisation in Africa hinges in part on the failure of states to respond to the pressing demands of their people (Fatton Jr. 1995). Yet others see civil society as more or less imaginary: 'outside of the sociological, historical and cultural events of its imagination, the existence or non-existence of 
civil society is not significant' (Tester 1992). Still others see civil society as the process by which society seeks to breach and counteract the simultaneous 'totalisation' unleashed by the state (Bayart 1989). Finally others simply define civil society as 'new spaces for communication and discussion over which the state has no control' (Monga 1998). The various definitions are limited by the fact that they are mostly Eurocentric, and this Eurocentrism has been difficult to deconstruct (Bratton 1989; Harbeson et al. 1994).

However the definitions are useful to the present work in that they provide some paradigms which will be borrowed and tasted. In the light of these definition civil society can be broadly understood as the domain of non-kinship-based contractual relations comprising interest groups such as traditional rulers, credit and development associations, student unions, Bar Associations, journalists' associations, religious groups and women and men in the informal sector. These organisations should exist independent of the state but at the same time be prime movers of societal dynamism. Civil society generally is pegged on a number of themes: to foster the spirit of democracy (Ceesay 1998), to mediate relations between the state and society, to set the rules and ethos of public conduct and to ensure that the state reflects the social reality and is committed to the pursuance of the public good (Osaghae 1998).

The role of civil society in societal transformation and nation-building in Cameroon has been compromised by political and social strictures deriving from three decades of autocratic rule that still underpin the practical and moral workings of the state. Civil society remains mired in societal cleavages that find expression in parochial tendencies ranging from neo-patrimonialism, clientelism, ethnicism to regionalism, thereby limiting its ability to mobilise citizens towards a meaningful democratic culture. In these circumstances the quest for good governance remains, for the vast majority, a platitudinous utopia. The pith and kernel of this paper is to examine the roots of civil society in Cameroon and its impact on the Cameroon body politic and to chart a new way forward for civil society in Cameroon.

\section{Ingredients of Cameroon's Civil Society}

Awasom (2005) has delineated the various components of Cameroon's civil society in the 1990s to avoid 'ambiguities'. My analysis does not, 
in a strict sense, diverge from this approach but will re-interpret it with available data where needed. Civil society is made up of individuals who have an interest in redressing political, economic and social abnormalities in the society. Students press their demands through student bodies, workers through trade unions or professional groupings, market traders through the formal or informal market associations and so forth. Sometimes several groups combine to make demands on government, especially when the levels of immiseration and deprivation have become unbearable (Osaghae 1994).

Civil society in Cameroon became quite vocal in the 1990s and was bent on 'opening and expanding the political space' (Awasom 2005). Various groups and organisations thirsted for freedom, justice, good governance. The initial group was made up of students and workers' unions. They emerged as the main critics of the regime against a backdrop of degrading conditions in the lone state university, the University of Yaounde, opened in 1961 more for political than academic objectives. By 1990 the university hosted more than 32,000 students, well beyond its carrying capacity, while graduates remained unemployed and the economy was souring (Nyamnjoh 1997; Konings and Nyamnjoh 1997). Traditional societies then emerged in the names of Takembeng and Anlu and were quite instrumental during the civil disobedience campaign and the post-October 1992 election results. As a matter of fact, democracy in Cameroon since 1990 has gone only as far as the political ritual of holding elections, all of which have been marred by gross irregularities and blatant disregard of the fundamental principles of democratic electioneering (Nyamnjoh 1999; Mbuagbo and Robert 2004)

Religious groups and organisations also became vibrant and vocal elements of civil society. The Bishops of the Bamenda ecclesiastical province addressed a 25-point letter to the Prime Minister, Simon Achidi Achu, asking the government to address the political, social and economic situation of the state. The church, especially the Roman Catholic Church, even went as far as hosting political party activities considered anathema by the state. A case in point was the All Anglophone Conference, which took place in Mount Mary Health Centre, Buea, in April 1993. The Social Democratic Front convention was also held several times at the church centre, Big Mankon, a citadel of the Ecclesiastical province. Even the Episcopal Conference came out with statements that were critical of the government. 
Meanwhile the Cameroon Bar Association did not remain numb in the search for a democratic space. When its ex-president and a prominent Barrister, John Mandengue Yondo Black, was arrested for attempting to form a party as a counterpoise to the ruling party, the arrest aroused the rage of the public against the state and brought demands for a more plural society to their apogee (Awasom 2005). Eventually political parties were given an official stamp by a regime that had held tight to change. These political parties questioned and criticised the lack of political space. On January 9, 1991, the Cameroon Tribune newspaper published a list of 4l registered political parties which by 2004 went far above 180 (Awasom 2005).

These were some of the constituents of civil society in Cameroon by the 1990s. So vibrant was it that the archaic and totalitarian system prevailing since 1961 was condemned to kowtow. However, judging from its modus operandi today, it is doubtful whether the civil society represents any way forward towards meaningful development in Cameroon. Does it really exist at all in Cameroon as the extant literature conceives it (Mbuagbo and Robert 2004; Orkin 1995; Abdelrahman $2000)$ ? Before attempting an answer, it is imperative for us to examine the roots of civil society in Cameroon. The next section therefore will examine the casus belli that gave rise to civil society.

\section{The Roots of Civil Society in Cameroon in the 1990s}

The roots of civil society in Cameroon in the 1990s are many and can be appreciated under economic, social and political rubrics. Economically the situation in Cameroon was bad and was aptly captured by a headline in La Nouvelle Expression, February 24-27, 1995, 'La Banque mondiale prévoit: encore un demi siècle de misère pour les Camerounaise' ('The World Bank Forecasts: Another Half-Century of Misery for Cameroonians').

Takougang and Krieger (1998) also provide very illuminating figures from the General Agreement on Tariffs (GATT) text on Cameroon. According to them real gross domestic product (GDP) per capita rose from US\$500 in 1970 to a peak near US\$1,200 in 1986 but then fell back to US $\$ 500$ by 1994 . The ratio of external debt to GDP doubled from 1986 to 1992. Net foreign direct investment from all sources of US\$300 million in 1985 became an US\$80 million disinvestment in 1990, while there was a 40 percent drop in the value of petroleum exports 
between 1990 and 1993. Between 1988 to 1992, Cameroon's productivity was the worst among forty-one African countries from which statistics were available (Takougang and Krieger 1998). The public service sector was in fragments. Salaries, which in any case were not paid regularly, dropped from 70 to 60 percent between 1990 and 1995. Retirement was enforced at 55 years of age or before, with pensions as problematic as salaries. The 100 percent CFA Franc devaluation in 1994 took an additional toll.

Socially, unemployment was near astronomical figures. University and professional—school graduates hardly picked up any job. Besides, an end to student bursaries and the introduction of school or registration fees caused untold disillusionment and frustration to many who could not even afford their 'daily bread'. To add insult to injury, many Cameroonians were deported from Gabon and felt more or less frustrated in Cameroon, as they remained idle, causing untold misery to themselves and their families.

Politically, the Cameroon of the 1990s was pegged on divide and rule, neo-patrimonialism, the politics of the belly, prebendalism, patronage, clientelism and so on (Bayart 1993; Konings and Nyamnjoh 1997; Nyamnjoh 1999). The net effect was that the Cameroon society, from the height of the state's level, appeared to be peopled exclusively by a multitude of private individuals chosen for their loyalty to the state rather than on merit. The Beti ethnic group from which the President comes occupied almost all the important positions in government (Poggi 1978; Ndembiyembe 1997). These people embezzled state resources without a 'modicum of morality' (Wiredu 1998).

The situation becomes very positive for the emergence of the civil society when absolute monarchical rule is arbitrary. Also, authoritarian regimes, in depoliticising as well as atomising their respective societies, give rise to civil societies. Here the civil society designs itself to change government policies (Holm et al. 1996; O'Donnel and Schmitter 1991). The Cameroon situation in the 1990s illustrates all the seeds that are necessary for a civil society to germinate. The next section of our paper will look at the ramifications of civil society on the body politic of Cameroon. 


\section{The Ramilications of Civil Society on the Body Politic of Cameroon}

The relationship between civil society and democracy is a complex one, and the emergence of a civil society does not guarantee the development of democracy. However it is highly unlikely that a viable democracy can survive without a civil society, because civil society is a necessary foundation for democracy (Woods 1992). It is within civil society that public opinion is formed and it is through independent associations that individuals can have some influence on government decision-making. Despite the fact that the Cameroon civil society had a bearing on at least the democratisation of the state, some African scholars have represented civil society as weak and unable to perform any effective role in promoting democracy (Bratton 1989) The Cameroon example has however shown the contrary. The movement from a monolithic one-party system to a multi-party system was one of the first fruits of the tree of civil society in Cameroon. In December 1990, after considerable pressure on the government, a series of laws to liberalise Cameroon's political landscape were promulgated. In the same year the University of Yaounde, the lone university in the country, was decentralised, and the Buea and Ngaoundere campuses were transformed into full-fledged universities. In a related vein the General Certificate of Education Board was created in 1993.

Cameroon has undergone four major elections since then-1992, 1997, 2002 and presidential elections in 2004-but after all these elections there has been general disenchantment with the electoral process due to massive rigging, non-registration of voters, low participation, unfulfilled promises and sterile political debates between the ruling party, the Cameroon's People Democratic Movement (CPDM), and the opposition parties. Despite these shortcomings one cannot deny that these elections came about largely as a result of pressure from the civil society in Cameroon since the 1990s. To be sure the civil society itself had shortcomings, firstly because it was led by human beings, some of whom only wanted to satisfy their bellies, but also because the government was unwilling to give up power. The next section of this paper will examine the flaws of civil society in Cameroon in the 1990s. 


\section{Drawbacks of Civil Society in Cameroon}

Whatever we say about civil society in Cameroon in the 1990s, it should be borne in mind that it was neither homogenous nor wholly emancipatory. In fact civil society was contradictory, exhibiting both democratic and despotic tendencies (Fatton Jr. 1995; Chabal 1994). The lack of homogeneity in the civil society in Cameroon can easily be explained on the basis of ethnicity. Cameroon is made up of approximately 240 ethnic groups (Takougang and Krieger 1998; Yenshu 2001), which helps keep civil society weak, as different indigenous groups and individuals pursue their own agendas (Bayart 1993). Moreover individuals belonging to elites were even given the go-ahead by the ruling regime to form ethnic associations to counter the opposition (Nyamnjoh and Michael 1998).

The pitfalls of civil society can also be explained by the role of the government. It is difficult for Cameroon to evolve a viable, inclusive and participatory governance structure due to its long history of autocratic rule, but this difficulty has been increased by the state's use of political stratagems such as divide-and-rule, prebendalism, patronage and clientelism, all of which have led to the informalisation of politics (Mbuagbo and Robert 2004; Bayart 1993; Konings 2002; Nyamnjoh 1999). Through these methods the ruling government has penetrated civil society and survived by 'buying off' sections of the civil society.

This happens because of mediocrity in leadership. Therefore, to achieve a sustainable and vibrant civil society in Cameroon, human resources development or capacity-building must be rekindled and kept alive (Forje 2003). Given the ideological individualism and the fear of subordinate classes, the elite individuals in civil society are prone to all sorts of opportunistic defections and personal accommodations with the authorities. The defections of Ahmadu Vamoulke to become the General Manager of Cameroon Radio and Television (CRTV) and a central committee member and of Bello Bouba Maigari to the camp of CPDM are classic cases in point (Nyamnjoh 1999). Thus individuals or groups within civil society were appeased or rewarded in order for rulers to stay in power. Coercion itself is expensive; the armed forces, police, paramilitary and presidential guard must all be satisfied if they are not to take power themselves (Chabal 1994). All these factors have rendered civil society weak in Cameroon. 
In addition university professors, teachers, tutors and rectors are disorganised and fragmented, preferring to accept sinecures and pursue narrow ethnic agendas rather than fight for their professional interests. With civil so-ciety divided amongst itself, the dynamic civil society of the 1990s has become a mirage fifteen years later. Today civil society in Cameroon has collapsed for a variety of reasons ranging from regionalism to the political acrobatics of the state. Non-governmental organisations have sprouted like mushrooms, but many exist only in suitcases and their leaders have no iota of civic responsibility. At this juncture, what can be done to enable civil society in Cameroon to play its desired role?

\section{Which Way Forward?}

This part of the paper attempts to suggest the way forward towards a viable, vibrant civil society in Cameroon. Although Cameroonian scholars such as Awasom (2005), Forje (2003), and Nyamnjoh (1999) have attempted to provide such a way forward for civil society in Cameroon, a concrete programme has not been adequately developed. My suggestions will therefore be specific to the Cameroon situation rather than globalised, although global paradigms will be borrowed when necessary. For close to fifteen years the civil society in Cameroon has remained in a morass, bespattered with societal cleavages which find expression in tendencies ranging from ethnicism to regionalism, thereby limiting its ability to mobilise the masses towards a meaningful democratic space.

The way out of this dismal situation requires civil society to transcend narrow, social and political boundaries and identify with the daily and legitimate struggles of ordinary citizens. Nyamnjoh (1999) argues that attempts to empower civil society in Cameroon have met with little success because of poor organisation, while Yenshu (2001) blames weak social mobilisation in a context of repressive laws that stifle real political and social debates. To overcome these problems civil society in Cameroon must therefore develop its capacity through a national network capable of developing a more consistent and coherent democratic discourse and of promoting practices and attitudes that defend the fundamental rights of citizens. This requires a synergy among the various elements of civil society to bring pressure to bear on all anti-democratic forces in the state. The experience in many other African countries, especially in South Africa, could be emulated in Cameroon. The 
contributions of mass political mobilisation and awareness-building among civil society organisations to achieve social transformation in South Africa should serve as an inspiration to budding civil society organisations in Cameroon (Orkin 1995).

The idea of civil society is not new, but what would appear to be new is its organisation within the modern state and its presupposition of a global character. According to De Oliveira and Tandon (1994) human beings have always come together for a common cause, and the gregarious nature of humankind is expressed in an associational life of diverse character and objectives. This diverse character, according to Bayart (1993), should include villagers, fishermen, nomads, members of different age groups, village councillors, slum dwellers and all others who are, or feel they are, without due access to state resources, as well as professionals, politicians, priest and mullahs, intellectuals, military officers. This human solidarity, with its historic and philosophical origins, is known as civil society and nowadays in Cameroon requires greater citizen participation and influence in the affairs of modern states than ever before.

Today there is empirical evidence of the existence of a plethora of movements in Cameroon within civil society, but most of these are in towns and cities. The most notorious of these movements are the NGOs. These NGOs are not only limited to towns and cities, but some do not even have offices. They exist in suitcases. Their limitation is also dictated by the fact that those who fund them dictate what they should do. Because of this, the interest of the masses is not reflected. Civil society deals with transforming the society; it therefore goes without saying that they must be built up from community levels and operate throughout the country. The mass of Cameroon's people live in the countryside; they need to be integrated into the new political culture and organised and educated through a bottom-up approach.

Civil society in Cameroon is anaemic and fractured. Mkandawire and Olukoshi (1995) maintain that a strong civil society is characterised by the existence of well-organised, highly elaborated, autonomous and self-conscious institutions and associational activities. These may be trade unions, religious or professional associations or traditional authorities. etc. In Zambia, for example, the politically effective characteristics of civil society are modern, while in Nigeria traditional power structures combine with modern ones to create a highly differentiated and articulate civil society. 
Current approaches in civil society represent the so-called neo-liberal explanations of social realities that have neo-colonial undertones. Richard Joseph (1978) aptly captures this as an 'ideological façade' designed to distract from a thorough empirical and theoretical explanation of Africa's social realities. Civil society in Cameroon has been stigmatised and asphyxiated since the postcolonial period (Gifford 1997). Today the Cameroon state, although a collapsed one, should take up its responsibility to empower and strengthen civil society. Some states are beginning to see the wisdom of strengthening civil society so that people's interests can be articulated effectively. For example Sierra Leone has been engaged in civil awareness programmes aimed at sensitising citizens about their civic rights. More needs to be done in this direction in Cameroon, and there is also a need to mount massive political awareness campaigns in order to sensitise both the state and civil society about their roles and responsibilities (Ceesay 1998). Cameroon could also go further to nurture a culture of tolerance, debate and accommodation in order to overcome the dangers of ethnic attachments. This can be achieved if specially trained people are employed to educate civil society groups in both urban and rural areas.

Osaghae (1998) maintains that the neo-liberal view pitches civil society as alternative, and even opposed to the state. This neo-liberal conceptualisation evolved and has been popularised within a narrowly defined ideological and historical moment, one which sees civil society as the spearhead and defender of economic and political liberalisation. In the same vein Mbuagbo and Robert (2004) maintain that a Eurocentric and unilinear perspective on civil society, like other development-oriented concepts, is not warranted by historical evidence. Mamdani (1995) argues that we are faced with the problem of viewing social phenomena out of context and imposing explanations not derived from empirical observations of actual social processes but by analogy from antecedent but different historical occurrences. In line with Mamdani this paper proposes autocentric research towards the understanding of civil society in Cameroon. This research should be long term and thoroughly grounded on methodology. Fundamental research should be conducted to come up with viable governance that will anchor the aspirations of the people. Today the Chinese are a challenge to the West because they took time in fundamental research. Research organisations such as the Council for the Development of Social Science Research in Africa (CODESRIA) should start funding meaningful 
research projects on civil society in Cameroon. The research should be manned by people with a high moral and intellectual reputation, since Cameroon has been named twice as the most corrupt country in the world.

To locate the role of civil society in the present political process in Cameroon is like searching for a pin in a haystack. Civil society has been paralysed by ethnic cleavages. The political liberalisation in Cameroon since 1990 has exposed dormant feelings of ethnic animosity, while pro-government vigilante groups emerged for various political reasons to counter the alliance between the minority Anglophones and Bamileke ethnic group that threatened to rob the ruling clique and their supporters of their political privileges (Konings 2002; Mbuagbo and Robert 2004). These ethnic fissures must be resolved and questions around citizenship and voting rights must not preoccupy the political agenda.

There is no doubt that civil society in Africa in general and Cameroon in particular is threatened by the particularism of ethnicity and other atomistic tendencies (Woods 1992). A fully developed civil society in Cameroon should help create norms that would limit the character of ethnic and cultural particularism. It is unlikely, however, that a civil society will develop in Cameroon that is completely void of ethnic tensions and divisions, but structures can be created to contain the problem. Civil society in Cameroon should be questioning its own raison d'etre like other human institutions. By cross-examining itself, it will know whether it is worthwhile. The growth of civil society requires organisational development to enable leaders to exercise influence over government on behalf of their members. When this type of institutionalisation exists, even authoritarian regimes such as the one in apartheid South Africa have to give grudging recognition to the civil society (Sklar 1987).

\section{Conclusion}

Civil society in Cameroon has failed to achieve its most important goalsocietal transformation. The reasons range from ethnicism to regionalism to elitism. The failure of the government to introduce democratic reforms is seen everywhere-from widespread abuses of human rights to the most blatant forms of corruption. These problems further inhibit the effectiveness of civil society in Cameroon in bringing about any 
meaningful change. To rescue itself from this banalised mire, civil society must transcends narrow ethnic, social and political boundaries and embrace the daily and legitimate struggles of ordinary citizens. This is the only way to move towards meaningful quantitative and qualitative development.

\section{References}

Abdelrahman, M., 2000, State Civil Society Relations: The politics of Egyptian NGOs, Ph.D Dissertation, ISS, The Hague.

Awasom, S. Y., 2005, 'The Vicissitudes of Cameroon Civil Society in the 1990s. What Lessons for the Central African Region?', in E.S.D Fomin and J. W Forje, eds. Central Africa: Crises, Reform and Reconstruction, Dakar: CODESRIA.

Bayart, J. F., 1993, The State in Africa: The Politics of the Belly, London: Longman.

Bratton M., 1989, 'Beyond the State: Civil Society and Associational Life in Africa', World Politics, Vol. 43, No. 3, pp. 407-430.

Carothers, T., 2000, 'Civil Society - The Key to Political Economic and Societal Success?' Deutschland, 5 October/November, pp. 12-17.

Ceesay, O., 1998, 'State and Civil Society in Africa', Quest, Vol. XII, No. 1, pp 123130.

Chabal, P., 1994, Political Domination in Africa: Reflections on the Limits of Power, Cambridge: Cambridge University Press.

Comaroff, L. and Comaroff, J., eds, 1999, Civil Society and the Political Imagination in Africa, Chicago: Chicago University Press.

De Oliveira M. D. and Tandon, R., 1994, 'An Emerging Global Civil Society', in S. Myers, ed., Democracy Is a Discussion, Connecticut: Toor Commings Center.

Fatton Jr., R., 1995, 'Africa in the Age of Democratisation: The Civic Limitations of Civil Society', African Studies Review, Vol. 38, No. 2, pp. 72-77.

Forje, J.W., 2003, 'Rethinking Social Responsibility and Governance for Sustainability: Lessons from Developing Polities in Africa', Journal of Applied Social, Vol. 3, No. 1, pp. 4-44.

Gifford, P., 1997, African Christianity: Its Public Role, London: Hurst.

Harbeson, J. W., David, R. and Naomi C., eds., 1994, Civil Society and the State in Africa, Boulder: Lynne Reinner.

Holm, J.D., Moluts P. P. and Somolekae, G., 1996, 'The Development of Civil Society in a Democratic State. The Botswana Model', African Studies Review, Vol. 39, No. 2, pp. 43-69.

Joseph, R., 1978, 'Introduction and General Framework', in R. Joseph, ed., Gaullist Africa: Cameroon under Ahmadu Ahidjo, Enugu: Fourth Dimensions.

Kasfir, N., ed., 1998, Civil Society and Democracy in Africa: Critical Perspectives, Ilford: Frank Lass.

Konings, P. and Nyamnjoh, F. B., 1997, 'The Anglophone Problem in Cameroon', Journal of Modern African Studies, Vol. 35, No. 2, pp. 215-235. 
Konings, P., 2002, 'University Students Revolt, Ethnic Militia and Violence during Political Liberalisation in Cameroon', African Studies Review, Vol. 45, No. 2, pp. 179-204.

Mamdani, M., 1995, 'A Critique of the State and Civil Society Paradigm in Africanist Studies', in M. Mamdani and E. Wamba-dia-Wamba, eds., African Studies in Social Movements and Democracy. Dakar: CODESRIA.

Mbuagbo, O. T. and Fru, C.N., 2003, Civil society and Democratisation: The Cameroonian Experience, Journal of Social Development in Africa, Vol. 18, No.2, pp. 133-149.

Mbuagbo, O. T., and Robert, M. A., 2004, 'Roll-Back: Democratisation and Social Fragmentation in Cameroon', Nordic Journal of African Studies, Vol. 13, No. 1, pp. $1-12$.

Mkandawire, T. and Adebayo O., eds., 1995, Between Liberalisation and Oppression: The Politics of Structural Adjustment in Africa, Dakar: CODESRIA.

Monga, C., 1998, The Anthropology of Anger: Civil society and Democracy in Africa, London: Lynne Rienner.

Ndembiyembe, P. C., 1997, 'Presse et tribalisme au Cameroun', in Gerddes, C., ed., La démocratie à l'épreuve du tribalisme, Yaounde: Saagraph, pp. 49-57.

Nyamnjoh, F. B., 1997, 'Media, Tribalism and Democracy in Cameroon, in Gerddes, C., ed., La démocratie à l'épreuve du tribalisme, Yaounde: Saagraph, pp. 59-80.

Nyamnjoh, F. B., 1999, 'Cameroon: a Country United by Ethnic Ambition and Difference', African Affairs, Vol. 98, No. 390, pp. 104-125.

Nyamnjoh, F. B. and Michael, R., 1998, 'Elite Associations and the Politics of Belonging in Cameroon', Africa, Vol. 68, No.3, pp. 321-337.

O'Donnel, G. and Schmitter, P. C., 1991, Transitions from Authoritarian Rule: Tentative Conclusions about Uncertain Democracies, Baltimore: John Hopkins University Press.

Orkin, M., 1995, 'Building Democracy in the New South Africa: Civil Society, Citizenship and Political Ideology', Review of African Political Economy, No.66, pp. 525537.

Osaghae, E. E., ed, 1994, Between state and Civil Society in Africa, Dakar: CODESRIA.

Osaghae, E.E., 1998, 'Rescuing the Post-Colonial State in Africa: A Reconceptualisation of the Role of Civil Society', Quest, Vol. XII, No.1, pp. 203206.

Poggi, G., 1978, The Development of the Modern State, Stanford: Stanford University Press.

Sitoe, E., 1998, 'State and Civil Society in Africa: An Instance of Asymmetric Interdependence', Quest, Vol. XII, No.1, pp. 203-216.

Sklar, R., 1987, 'Developmental Democracy', Comparative Studies in Society and History, Vol. 29, No.4, pp. 686-714.

Takougang, J. and Krieger, M., 1998, African State and Society in the 1990s: Cameroon's Political Crossroads, Boulder: Westview Press.

Wiredu, K., 1998, 'The State, Civil Society and Democracy in Africa', Quest, Vol. 12, No.1, pp. 241-253. 
Woods, D., 1992, 'Civil Society in Europe and Africa: Limiting State Power through a Public Sphere', African Studies Review, Vol. 35, No.2, pp. 77-100.

Yenshu, E., 2001, 'Social Movements and Political Parties during the Structural Adjustment Programme in Cameroon: A Critical Survey of Some Literature', paper presented at Third World Forum, Dakar, 14-16 April. 